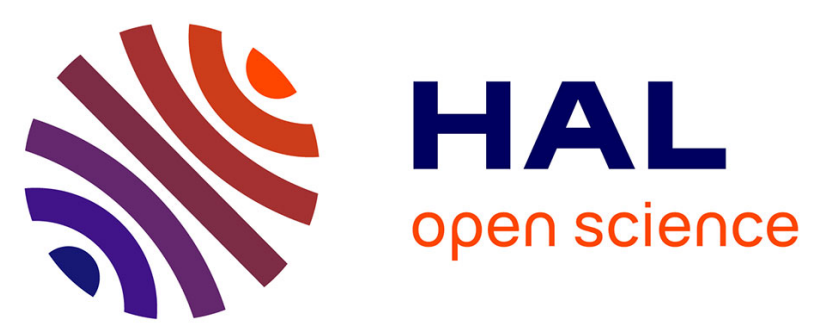

\title{
Stimulation of spermiation in carp in response to LH-RH and D-Ala6-LH-RH ethylamide
}

\author{
Roland Billard, J.P. Choisis, Pierrette Reinaud
}

\section{To cite this version:}

Roland Billard, J.P. Choisis, Pierrette Reinaud. Stimulation of spermiation in carp in response to LH-RH and D-Ala6-LH-RH ethylamide. Aquaculture, 1983, 35, pp.173-176. 10.1016/00448486(83)90085-6 . hal-01601333

\section{HAL Id: hal-01601333 \\ https://hal.science/hal-01601333}

Submitted on 2 Jun 2020

HAL is a multi-disciplinary open access archive for the deposit and dissemination of scientific research documents, whether they are published or not. The documents may come from teaching and research institutions in France or abroad, or from public or private research centers.
L'archive ouverte pluridisciplinaire HAL, est destinée au dépôt et à la diffusion de documents scientifiques de niveau recherche, publiés ou non, émanant des établissements d'enseignement et de recherche français ou étrangers, des laboratoires publics ou privés.

\section{다(1)(2)}

Distributed under a Creative Commons Attribution - ShareAlikel 4.0 International 


\title{
Short Communication
}

\section{STIMULATION OF SPERMIATION IN CARP IN RESPONSE TO LH-RH AND D-Ala ${ }^{6}$-LH-RH ETHYLAMIDE}

\author{
R. BILLARD, J.P. CHOISIS* and PIERRETTE REINAUD
}

Laboratoire de Physiologie des Poissons, INRA, 78350 Jouy-en-Josas (France)

and

*Campus de Beaulieu, 35042, Rennes (France)

(Accepted 20 December 1982)

\section{ABSTRACT}

Billard, R., Choisis, J.P. and Reinaud, P., 1983. Stimulation of spermiation in carp in response to LH-RH and D-Ala'-LH-RH ethylamide. Aquaculture, 35: 173-176.

The present experiment shows that spermiation was stimulated in the common carp following the injection of LH-RH and its alanine ${ }^{6}$ LH-RH ethylamide analog (LRH-A). The response was maximal at doses of $50 \mu \mathrm{g} / \mathrm{kg}$ body weight of LH-RH and $10 \mu \mathrm{g} / \mathrm{kg}$ body weight of LRH-A. Giving a higher dose of LRH-A $(50 \mu \mathrm{g} / \mathrm{kg})$ did not further increase the volume of milt collected.

\section{INTRODUCTION}

The number of spermatozoa harvested from the common carp (Cyprinus carpio) is usually low compared to the number produced during spermatogenesis and remaining in the testis. In induced reproduction and artificial insemination, it is desirable to increase the number of available spermatozoa by stimulating spermiation. Carp pituitary extracts are usually used for this purpose (Clemens and Grant, 1964, 1965; Rothbard and Rothbard, 1982), but other hormones should be tested. Among these, HCG has proved to be ineffective (F. Takashima, unpublished data, 1981), and LH-RH has been widely used in Chinese carp (Chinese National Bureau of Aquatic Products, 1980).

The present paper compares the effectiveness of synthetic LH-RH's on the production of spermatozoa in carp.

\section{MATERIAL AND METHODS}

We used adult male carp raised on the fish-farm at Jouy-en-Josas in recycled, filtered water (Petit, 1974). The fish were about 7 years old and weighed between 1 and $2 \mathrm{~kg}$. They were visually separated from the females and kept under natural photoperiod at $10-13^{\circ} \mathrm{C}$ throughout the experiment. 
The fish, usually fed commercial pellets at a rate of $1 \%$ of body weight, were starved during the present experiment which took place between April and May. They were divided into 5 groups each of 10 fish. Two groups were given a daily intraperitoneal injection of LH-RH (Sigma) at a dose of 10 or $50 \mu \mathrm{g} / \mathrm{kg}$ of body weight for 4 days. Two other groups received a similar treatment of LH-RH analog (LRH-A) (D-Ala ${ }^{6}$-Des Gly ${ }^{10}$ LH-RH ethylamide, Sigma). Group 5 was given only the solvent ( $500 \mu \mathrm{l} / \mathrm{kg}$ body weight of a $\mathrm{NaCl}$ solution at $7 \mathrm{~g} / \mathrm{l}$ ). The fish were injected at about 10 a.m. On days 4 and 5 we measured the volume of sperm collected by squeezing the abdomen. On day 5 an aliquot of the sperm of each male was diluted by 1/3000 in saline solution at $7 \mathrm{~g} / \mathrm{l}$ in order to measure the optical density (OD) (spectrophotometer Jobin and Yvon $10 \mathrm{~L}$ at $410 \mathrm{~nm}$ ) and estimate the concentration of spermatozoa. Before any injection or sampling the males were anesthesized with phenoxy-ethanol $(0.5 \mathrm{ml} / \mathrm{l})$ and put in a bath of malachite green (15 $\mathrm{mg} / \mathrm{l}$ for $30 \mathrm{~s}$ to $1 \mathrm{~min}$ ).

The doses were compared statistically by analysis of variance and covariance (body weight and sperm volume). The results on the two neurohormones were compared by a non-parametric method (Kruskal-Wallis test) because the variances were not homogeneous.

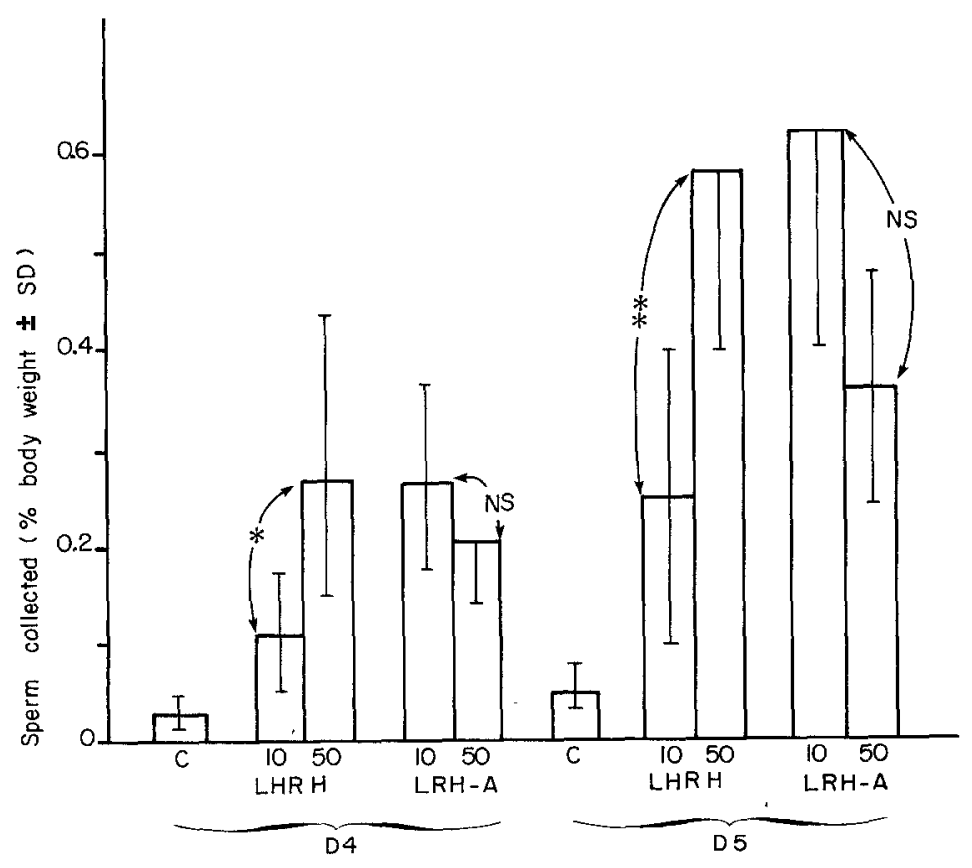

Fig. 1. Volume of milt collected in common carp 4 (D4) and 5 (D5) days after injection of 10 and $50 \mu \mathrm{g} / \mathrm{kg}$ body weight of LH-RH and LRH-A. C: control group receiving only the solvent. 


\section{RESULTS}

The results obtained on the volume of milt harvested, presented in Fig. 1, are expressed in percent of body weight. The volume of collected milt was at D4 lower than at D5. The responses were very similar on both days, i.e. significantly higher production of spermatozoa with $50 \mu \mathrm{g}$ than with $10 \mu \mathrm{g}$ of LH-RH, whereas LRH-A responses were not increased at $50 \mu \mathrm{g}$ in comparison with $10 \mu \mathrm{g}$. In all cases, strong individual variations were observed, e.g. at D5 the volume of collected sperm varied between 2.2 and $13.7 \mathrm{ml}$ after treatment with $10 \mu \mathrm{g}$ of LRH-A. The controls which received only the solvent produced a smaller number of spermatozoa. Spermatozoal concentrations did not vary significantly between treatments, the OD varying between $0.19 \pm 0.01$ and $0.21 \pm 0.03$, i.e., between 20.9 and 23.1 billions of spermatozoa per $\mathrm{ml}$ of milt.

\section{DISCUSSION}

This study showed that spermation in the carp was stimulated by administering a gonadotropin releasing hormone. This stimulation resulted in an increase in milt volume and in the number of spermatozoa. The response increased siginificantly with a dose of mammalian decapeptide (LH-RH). Maximal response to LRH-A was obtained with a dose of $10 \mu \mathrm{g} / \mathrm{kg}$; no further increase occurred at a dose of $50 \mu \mathrm{g} / \mathrm{kg}$. These doses were relatively high compared with those which are effective in mammals, but they are lower than that needed to induce ovulation in the common carp (at least $50 \mu \mathrm{g}-\mathrm{Kung}$ pers. commun., 1982; L.W. Crim, K. Bieniarz, R.E. Peter and R. Billard, unpublished data, 1981). At a lower dose (e.g. $1 \mu \mathrm{g} / \mathrm{kg}$ of LRH-A) the response is very low ( $F$. Takashima, unpubl. data, 1981) in carp, whereas it is greater in other species such as grass carp (Kung, pers. commun., 1982). It should be noted that the water temperature was relatively low in our experiment. LRH-A was also successfully used to advance the onset of spermiation in landlocked salmon (Weil and Crim, 1982, 1983). This method of stimulating spermiation may be used as a test for roughly assessing the biological activity of $\mathrm{GnRH}$, which is easy to use in fish farms, as suggested for carp pituitary extracts (Rothbard and Rothbard, 1982). In fact, the biological activity of various GnRH preparations presently on the market is not indicated, and the fish-farmer and scientist can only refer to the weight of the products. Unfortunately, while this test can be used for LH-RH, it is not entirely valid for LRH-A because the response to the highest dose used here $(50 \mu \mathrm{g} / \mathrm{kg})$ was not increased and, in fact even decreased. Such a suppression of response to a high dose has already been reported for goldfish in which several LRH-A injections at high doses, compared to lower doses, caused a decrease in plasma GtH secretion (Peter, 1980). 


\section{ACKNOWLEDGEMENTS}

We thank Mrs. A. Daifuku for the English translation and Dr. L.W. Crim for reading the manuscript. The work was supported by a CNRS-CNEXO Grant (Bases biologiques de l'aquaculture).

\section{REFERENCES}

Chinese National Bureau of Aquatic Products, 1980. Pond Fish Culture in China. Pearl River Fisheries Research Institute, Guangzhou, China, 136 pp.

Clemens, H.P. and Grant, F.B., 1964. Gonadal hydration of carp (Cyprinus carpio) and goldfish (Carassius auratus) after injections of pituitary extracts. Zoologica, 49: 193-210.

Clemens, H.P. and Grant, F.B., 1965. The seminal thinning response of carp (Cyprinus carpio) and rainbow trout (Salmo gairdneri) after injections of pituitary extracts. Copeia, pp. 174-177.

Petit, J., 1974. Recyclage et épuration en pisciculture: étude théorique et bibliographique. Coll. Aqua. CNEXO, Brest, pp. 445-470.

Peter, R.E., Serum gonadotropin levels in mature male goldfish in response to luteinizing hormone-releasing hormone $(\mathrm{LH}-\mathrm{RH})$ and Des Gly ${ }^{10}-\left(\mathrm{D}-\mathrm{Ala}^{6}\right) \mathrm{LH}-\mathrm{RH}$ ethylamide. Can. J. Zool., 58: 1100-1104.

Rothbard, S. and Rothbard, H., 1982. Spermiation response of carp to homologous pituitary gland. In: C.J.J. Richter and H.J.Th. Goos (Editors), Reproductive Physiology of Fish. PUDOC, Wageningen, p. 201.

Weil, C. and Crim, L.W., 1982. A study of methods of administering LHRH analogs: advancement of spermiation in the landlocked salmon (Salmo salar). In: C.J.J. Richter and H.J.Th. Goos (Editors), Reproductive Physiology of Fish. PUDOC, Wageningen, p. 26.

Weil, C. and Crim, L.W., 1983. Administration of LHRH analogues in various ways: effect on the advancement of spermiation in prespawning landlocked salmon, Salmo salar. Aquaculture, 35: 103-115. 